\title{
Is enteral nutrition a primary therapy in cancer patients?
}

\author{
F Bozzetti
}

Istituto Nazionale Tumori, Milan, Italy F Bozzetti

Correspondence to: Nazionale Tumori, Via Venezian 1, 20133 Milan, Italy. Professor F Bozzetti, Istituto

\begin{abstract}
At present, there is limited evidence for the role of enteral nutrition as a primary therapy in cancer patients. Cachexia commonly occurs in patients with advanced cancer. A consensus view from a large number of studies suggests that cachexia cannot be fully reversed by vigorous enteral nutritional support. A review is included of the available data on the effects of enteral nutritional support on the common indices of nutritional state and on the final outcome of patients receiving enteral nutrition in conjunction with radiotherapy or chemotherapy, or both. The 'nutritional' effects are probably limited because the duration of the nutritional support in most studies consists of a few weeks while malnutrition in the cancer patients often occurs over many months.

(Gut 1994; supplement 1: S65-S68)
\end{abstract}

TABLE I The effect of enteral nutrition on body weight, body fat, indices of muscular mass, and lean body mass

\begin{tabular}{|c|c|c|c|c|c|}
\hline \multirow[b]{2}{*}{ Tumour site } & \multicolumn{2}{|c|}{ Regimen per kg per day } & \multirow{2}{*}{$\begin{array}{l}\text { Duration } \\
\text { (days) }\end{array}$} & \multirow[b]{2}{*}{ Results ${ }^{\star}$} & \multirow[b]{2}{*}{ Authors } \\
\hline & $k c a l$ & $N^{2}$ & & & \\
\hline \multicolumn{6}{|l|}{ Body weight } \\
\hline Oesophagus & 63 & 0.35 & 21 & + & Lim et $a l^{4}$ \\
\hline Oesophagus & 44 & $0 \cdot 14$ & 14 & $=$ & Burt et al ${ }^{56}$ \\
\hline Oesophagus & 37 & 0.33 & 35 & $=$ & Cozzaglio et $a l^{7} \ddagger$ \\
\hline Head-neck & 34 & $0 \cdot 20$ & 49 & $=$ & Balzola et $a l^{8} \dagger$ \\
\hline Head-neck & 49 & $0 \cdot 30$ & 49 & + & Balzola et $a l^{8} \dagger$ \\
\hline Head-neck & 39 & $0 \cdot 24$ & 28 & $=$ & Daly et $a l^{9} t$ \\
\hline Gastrointestinal & 44 & $0 \cdot 20$ & 15 & $=$ & Braga et al ${ }^{10}$ \\
\hline Heterogeneous & 35 & $0 \cdot 21$ & 14 & + & Bennegard et al ${ }^{11}$ \\
\hline Heterogeneous & 43 & $0 \cdot 28$ & 28 & + & Cristallo et al ${ }^{12}$ \\
\hline Heterogeneous & 42 & $0 \cdot 38$ & 18 & + & Ravera $e t a l^{13}$ \\
\hline Heterogeneous & 58 & $0 \cdot 19$ & 14 & + & James et $a l^{14}$ \\
\hline \multicolumn{6}{|c|}{ Body fat (triceps skinfold) } \\
\hline Gastrointestinal & 44 & $0 \cdot 20$ & 15 & $=$ & Braga et al ${ }^{10}$ \\
\hline Heterogeneous & 35 & 0.21 & 14 & $=$ & Bennegard et al ${ }^{11}$ \\
\hline Heterogeneous & 43 & $0 \cdot 28$ & 28 & + & Cristallo et al ${ }^{12}$ \\
\hline Heterogeneous & 42 & $0 \cdot 38$ & 18 & & Ravera $e t a l^{13}$ \\
\hline Heterogeneous & 58 & $0 \cdot 19$ & 14 & $+\mathrm{TBF}$ & James et al ${ }^{14}$ \\
\hline \multirow{2}{*}{\multicolumn{6}{|c|}{$\begin{array}{l}\text { Indices of muscular mass } \\
\text { Arm muscle circumference }\end{array}$}} \\
\hline & & & & & \\
\hline Head-neck & 38 & $0 \cdot 24$ & 28 & $=$ & Daly $e t a l^{9}$ \\
\hline Gastrointestinal & 44 & $0 \cdot 20$ & 15 & $=$ & Braga et al ${ }^{10}$ \\
\hline Heterogeneous & 43 & $0 \cdot 28$ & 28 & + & Cristallo et al ${ }^{12}$ \\
\hline $\begin{array}{l}\text { Heterogeneous } \\
\text { Urinary creatinine }\end{array}$ & 42 & $0 \cdot 38$ & 18 & $=$ & Ravera $e t a l^{13}$ \\
\hline Heterogeneous & 35 & $0 \cdot 21$ & 14 & $=$ & Bennegard et al ${ }^{11}$ \\
\hline $\begin{array}{l}\text { Heterogeneous } \\
\text { Urinary 3-methylhistid }\end{array}$ & 42 & $0 \cdot 38$ & 18 & $=$ & Ravera et $a l^{13}$ \\
\hline $\begin{array}{l}\text { Urinary 3-methylhistid } \\
\text { Oesophagus } \\
\text { 3-Methylhistidine efflu }\end{array}$ & 44 & $0 \cdot 14$ & 14 & $=$ & Burt et $a l^{6}$ \\
\hline \multicolumn{2}{|c|}{ 3-Methylhistidine efflux (from the leg) } & eg) & 14 & - & Lundholm et al 15 \\
\hline Tyrosine efflux & & & & & \\
\hline $\begin{array}{l}\text { Heterogeneous } \\
A A \text { and } B C A A \text { efflux }\end{array}$ & 37 & $0 \cdot 17$ & 14 & $=$ & Lundholm et al ${ }^{15}$ \\
\hline Heterogeneous & 40 & $0 \cdot 24$ & 14 & $=$ & Bennegard et al ${ }^{16}$ \\
\hline \multicolumn{6}{|l|}{ Lean body mass } \\
\hline Nitrogen balance & & & & & \\
\hline Oesophagus & 77 & $0 \cdot 41$ & $7-21$ & pos & Haffejee and Angorn ${ }^{17}$ \\
\hline Oesophagus & 44 & $0 \cdot 14$ & 14 & $=$ & Burt et $a l^{5}$ \\
\hline Heterogeneous & 35 & $0 \cdot 21$ & 14 & pos & Bennegard et al ${ }^{11}$ \\
\hline $\begin{array}{l}\text { Heterogeneous } \\
\text { Total body nitrogen }\end{array}$ & 42 & $0 \cdot 38$ & 18 & pos & Ravera et al $l^{13}$ \\
\hline $\begin{array}{l}\text { Heterogeneous } \\
\text { Whole body potassium }\end{array}$ & 58 & $0 \cdot 19$ & 14 & $=?$ & James et al ${ }^{14}$ \\
\hline Oesophagus & 44 & $0 \cdot 14$ & 14 & $=$ & Burt et $a l^{5}$ \\
\hline Heterogeneous & 35 & 0.21 & 14 & + & Bennegard et al ${ }^{11}$ \\
\hline Heterogeneous & 58 & $0 \cdot 19$ & 14 & + & James et al ${ }^{14}$ \\
\hline
\end{tabular}

${ }^{\star}+$, increase; - , decrease; $=$, no change; pos, positive; TBF, total body fat; tradiotherapy; tradiotherapy plus chemotherapy; $\mathrm{AA}=$ amino acids; $\mathrm{BCAA}=$ branched chain amino acids.
There is some evidence that enteral nutrition is probably not successful as a primary therapy in many patients with the cancer cachexia syndrome. The suggestion derives from metabolic balance studies done in humans.

The techniques used to undertake such studies are based on the assumption that certain elements are found in comparatively fixed proportions in normal lean body mass. If an organism retains these elements in these ratios, it may be right to assume that normal lean body mass is being formed; conversely significant deviation from these ratios, as occurs in cancer patients, means that normal lean body mass is not being repleted and that the elements retained are being used for other purposes.

In certain circumstances, however, enteral nutrition may be useful in cancer patients whose weight loss is exacerbated by such complications as fistulas, short bowel obstruction, and vomiting or malabsorption induced by the tumour itself or the treatment. There may also be patients who, at different times in the course of their disease, may gain transient benefit from nutritional support.

In this paper we will discuss the effects of enteral nutrition on the nutritional state of cancer patients and its role in conjunction with other treatments. Finally, the possible effect of enteral nutrition on tumour growth in humans is discussed.

\section{Enteral nutrition and nutritional state}

Although the first controversial papers on nasogastric feeding with milk based formulas date back to the $1950 \mathrm{~s},{ }^{1-3}$ substantial experience has been gained in the past decade (Table I).

Enteral nutrition can increase body weight (even during chemotherapy ${ }^{18}$ ) mainly as a result of accumulation of body fat, whereas indices of muscle mass (arm muscle circumference, urinary excretion of creatinine and 3methylhistidine) as well as amino acid efflux from the leg are only slightly affected by the nutritional support.

Studies on nitrogen balance and whole body potassium point to an increase in lean body mass, whereas no substantial data exist on total body nitrogen. Total protein, transferrin, cholinesterase, thyroxine binding prealbumin and ceruloplasmin concentrations as well as protein kinetics are in general unaffected by the treatment, and results concerning the effect of enteral nutrition on serum albumin concentrations are conflicting (Table II).

With regard to immune function, increases in some fraction of the complement cascade have been described and in a number of studies increases in lymphocyte counts have been reported (Table III). 
TABLE II The effect of enteral nutrition on serum proteins and whole body protein kinetics

\begin{tabular}{|c|c|c|c|c|c|}
\hline \multirow[b]{2}{*}{ Tumour site } & \multicolumn{2}{|c|}{ Regimen per kg per day } & \multirow{2}{*}{$\begin{array}{l}\text { Duration } \\
\text { (days) }\end{array}$} & \multirow[b]{2}{*}{ Results $^{\star}$} & \multirow[b]{2}{*}{ Authors } \\
\hline & kcal & $N^{2}$ & & & \\
\hline \multicolumn{6}{|l|}{ Serum proteins } \\
\hline \multicolumn{6}{|l|}{ Total protein } \\
\hline Oesophagus & 44 & $0 \cdot 14$ & 14 & $=$ & Burt et $a l^{6}$ \\
\hline Oesophagus & 37 & 0.33 & 35 & $=$ & Cozzaglio et al $\ddagger^{7}$ \\
\hline Head-neck & 49 & $0 \cdot 30$ & 49 & $=$ & Palmo et al $\dagger^{19}$ \\
\hline Heterogeneous & 42 & $0 \cdot 38$ & 18 & $=$ & Ravera et $a l^{13}$ \\
\hline $\begin{array}{l}\text { Albumin } \\
\text { Oesophagus }\end{array}$ & 44 & $0 \cdot 14$ & 14 & - & Burt et $a l^{6}$ \\
\hline Oesophagus & 37 & 0.33 & 35 & $=$ & Cozzaglio et al $\ddagger^{7}$ \\
\hline Head-neck & 39 & $0 \cdot 24$ & 28 & - & Daly et al $\dagger^{9}$ \\
\hline Head-neck & 49 & $0 \cdot 30$ & 49 & $=$ & Palmo et al $\dagger^{19}$ \\
\hline Gastrointestinal & 44 & $0 \cdot 20$ & 15 & $=$ & Braga et al ${ }^{10}$ \\
\hline Heterogeneous & 35 & $0 \cdot 21$ & 14 & $=$ & Bennegard et al ${ }^{1}$ \\
\hline Heterogeneous & 43 & $0 \cdot 28$ & 28 & + & Cristallo et al ${ }^{12}$ \\
\hline Heterogeneous & 42 & $0 \cdot 38$ & 18 & $=$ & Ravera $e t a l^{13}$ \\
\hline \multicolumn{6}{|l|}{ Total iron binding capacity } \\
\hline Oesophagus & 44 & $0 \cdot 14$ & 14 & $=$ & Burt $e t a l^{6}$ \\
\hline Gastrointestinal & 44 & $0 \cdot 20$ & 15 & $=$ & Braga et al ${ }^{10}$ \\
\hline Heterogeneous & 43 & $0 \cdot 28$ & 28 & + & Cristallo et al ${ }^{12}$ \\
\hline Heterogeneous & 42 & 0.38 & 18 & $=$ & Ravera $e^{a} a^{13}$ \\
\hline \multicolumn{6}{|l|}{ Cholinesterase } \\
\hline Oesophagus & 37 & 0.33 & 35 & $=$ & Cozzaglio et al $\neq^{7}$ \\
\hline Head-neck & 49 & $0 \cdot 30$ & 49 & $=$ & Palmo et al $\dagger^{19}$ \\
\hline Heterogeneous & 43 & $0 \cdot 28$ & 28 & + & Cristallo et al ${ }^{12}$ \\
\hline Heterogeneous & 42 & $0 \cdot 38$ & 18 & $=$ & Ravera $e t a l^{13}$ \\
\hline $\begin{array}{l}\text { Thyroxin binding prealbumin } \\
\text { Head-neck }\end{array}$ & 49 & $0 \cdot 30$ & 49 & + & Palmo et al $\dagger^{19}$ \\
\hline Heterogeneous & 35 & $0 \cdot 21$ & 14 & $=$ & Bennegard $e t a l^{1}$ \\
\hline Ceruloplasmin & $A$ & & & & \\
\hline \multirow{2}{*}{\multicolumn{6}{|c|}{ Whole body protein kinetics }} \\
\hline & & & & & \\
\hline $\begin{array}{l}\text { Protein flux synthesis, } \\
\text { catabolism }\end{array}$ & 44 & $0 \cdot 14$ & 14 & $=$ & Burt $e t a l^{6}$ \\
\hline
\end{tabular}

${ }^{\star}+$, increase; - , decrease; =, no change; tradiotherapy; $¥$ radiotherapy plus chemotherapy.

In general the data suggest a limited efficacy of enteral nutrition in restoring a depleted nutritional state; most commonly, nutritional state is maintained as a consequence of enteral nutrition.

A number of studies have now been carried out to compare the efficacy of enteral nutrition in cancer and non-cancer patients (Table IV).

Cancer patients receiving enteral nutrition show smaller increases in body weight, arm muscle circumference, and some mineral balances than non-cancer patients. Dresler et $a l^{21}$ recently investigated the metabolic efficacy of enteral feeding in malnourished cancer and non-cancer patients. They showed that a defined enteral diet with a calorie: nitrogen ration of $200: 1$ prescribed to $120 \%$ of the basal

TABLE III The effect of enteral nutrition on humoral immune response and non specific cellular response

\begin{tabular}{|c|c|c|c|c|c|}
\hline \multirow[b]{2}{*}{ Tumour site } & \multicolumn{2}{|c|}{ Regimen per kg per day } & \multirow{2}{*}{$\begin{array}{l}\text { Duration } \\
\text { (days) }\end{array}$} & \multirow[b]{2}{*}{ Results $^{\star}$} & \multirow[b]{2}{*}{ Authors } \\
\hline & kcal & $N^{2}$ & & & \\
\hline \multicolumn{6}{|c|}{ Humoral immune response } \\
\hline $\begin{array}{l}I g G, I g A, I g M \\
\text { Oesophagus }\end{array}$ & 77 & $0 \cdot 41$ & $7-21$ & $=$ & $\begin{array}{c}\text { Haffejee and } \\
\text { Angorn }^{17}\end{array}$ \\
\hline $\begin{array}{l}C 3, C 3, C 3 P A \\
\text { Oesophagus }\end{array}$ & 77 & $0 \cdot 41$ & $7-12$ & + & $\begin{array}{c}\text { Haffejee and } \\
\text { Angorn }{ }^{17}\end{array}$ \\
\hline $\begin{array}{l}\mathrm{C3} \\
\text { Gastrointestinal } \\
\mathrm{CH} 50\end{array}$ & 44 & $0 \cdot 20$ & 15 & + & Braga et $a l^{4}$ \\
\hline Oesophagus & 77 & 0.41 & $7-21$ & $=$ & $\begin{array}{c}\text { Haffejee and } \\
\text { Angorn }^{17}\end{array}$ \\
\hline \multicolumn{6}{|c|}{$\begin{array}{l}\text { Non-specific cellular response } \\
\text { Lymphocytes }\end{array}$} \\
\hline Oesophagus & 77 & 0.41 & $7-21$ & + & $\begin{array}{c}\text { Haffejee and } \\
\text { Angorn }^{17}\end{array}$ \\
\hline Gastrointestinal & 44 & $0 \cdot 20$ & 15 & $=$ & Braga et $a l^{4}$ \\
\hline $\begin{array}{l}\text { Heterogeneous } \\
\text { T lymphocytes }\end{array}$ & 42 & $0 \cdot 38$ & 18 & + & Ravera $e t a l^{4}$ \\
\hline Oesophagus & 77 & 0.41 & $7-12$ & + & $\begin{array}{c}\text { Haffejee and } \\
\text { Angorn }{ }^{17}\end{array}$ \\
\hline $\begin{array}{l}B, T, N, F T \text { lymph } \\
\text { Oesophagus }\end{array}$ & $\begin{array}{r}\text { cytes } \\
77\end{array}$ & $0 \cdot 41$ & $7-12$ & $=$ & $\begin{array}{c}\text { Haffejee and } \\
\text { Angorn }^{17}\end{array}$ \\
\hline
\end{tabular}

$\star+$, increases; $=$, no change.
TABLE IV Response to enteral nutrition in cancer $\mathrm{v}$ noncancer patients 120

\begin{tabular}{lll}
\hline & \multicolumn{2}{l}{ Enteral nutrition } \\
\cline { 2 - 3 } Category & Cancer & Non-cancer \\
\hline Weight & + & ++ \\
Arm circumference & + & + \\
Triceps skinfold & $=$ & + \\
& + & + \\
Arm muscle area & $=$ & + \\
Creatinine-height index & + & + \\
Nitrogen balance & + & + \\
& + & + \\
Total body potassium & + & + \\
Tyrosine balance & + & + \\
Albumin & $=$ & + \\
& + & + \\
Prealbumin & $=$ & $=$ \\
Retinol binding protein balance of: & & $=$ \\
Na & - & + \\
$\mathrm{K}$ & - & + \\
$\mathrm{Cl}$ & - & + \\
$\mathrm{Mg}$ & - & + \\
$\mathrm{P}$ & + & + \\
$\mathrm{Ca}$ & + & + \\
& &
\end{tabular}

+ , increase; ++ , greater increase; - , decrease; $=$, no change.

energy expenditure resulted in an equivalent suppression of endogenous glucose production, suppression of alanine to glucose conversion, attainment of positive nitrogen balance, and suppression of protein catabolism. After two weeks of enteral support, however, cancer patients differed from non-cancer patients by having significantly raised lactate concentrations, decreased plasma glycine concentrations, and inability to replenish fat stores. Furthermore, cancer patients had a significant reduction in whole body protein synthesis rates whereas non-cancer patients showed no significant change.

These data suggest that there are metabolic abnormalities besides simple starvation and underfeeding that play a part in cancer malnutrition and that these in turn are difficult to reverse by nutritional support.

\section{Randomised studies on perioperative enteral nutrition}

PREOPERATIVE ENTERAL $v$ TOTAL PARENTERAL NUTRITION

Lim $e^{a l}{ }^{4}$ randomly assigned 24 patients with carcinoma of the oesophagus to receive either total parenteral nutrition (12 patients) or enteral nutrition given by a gastrostomy tube (12 patients) for three weeks before surgery. Weight gain was significantly greater in the total parenteral nutrition group whereas improvement in serum albumin concentrations was similar in both groups. The lower morbidity and mortality seen in the total parenteral nutrition group was not statistically significant, probably, in part, because of the small numbers investigated.

Sako et al ${ }^{22}$ prospectively randomised 69 patients to receive total parenteral nutrition or enteral nutrition before surgery for head and and neck cancer. Nutritional support was given for 14 days. Nitrogen balance was significantly better in the total parenteral nutrition group but no differences were found in the incidence of postoperative complications or death.

These studies suggest that when adequate amounts of nutrients are given in the preopera- 
TABLE V Nutritional state in patients with cancer of the oesophagus receiving chemotherapy and radiotherapy ${ }^{7}$

\begin{tabular}{|c|c|c|c|c|}
\hline \multirow[b]{2}{*}{ Patients } & \multicolumn{2}{|c|}{ Enteral nutrition ${ }^{\star}(n=20)$} & \multicolumn{2}{|c|}{ Control $(n=17)$} \\
\hline & $b$ & $a$ & $b$ & $a$ \\
\hline $\begin{array}{l}\text { Weight }(\mathrm{kg}) \\
\text { Protein }(\mathrm{g} / \mathrm{dl}) \\
\text { Albumin }(\mathrm{g} / \mathrm{dl}) \\
\text { Cholinesterase (mU/ml) }\end{array}$ & $\begin{array}{r}55 \cdot 4 \\
6.9 \\
3.9 \\
1921\end{array}$ & $\begin{array}{r}55 \cdot 4 \\
6 \cdot 9 \\
3 \cdot 8 \\
2107\end{array}$ & $\begin{array}{r}54 \cdot 2 \\
7 \cdot 1 \\
4 \cdot 0 \\
1925\end{array}$ & $\begin{array}{r}52 \cdot 3^{\star \star} \\
6 \cdot 5^{\star \star} \\
3 \cdot 5^{\star \star} \\
1838\end{array}$ \\
\hline
\end{tabular}

$\star 37 \mathrm{kcal} / \mathrm{kg}^{-1} / \mathrm{d}^{-1}$ and $2 \cdot 1 \mathrm{~g}$ protein $/ \mathrm{kg}^{-1 / \mathrm{d}^{-1} ; \star \star} \mathrm{p}=0.05$.

tive period, there are no advantages in giving them by either the enteral or parenteral route. This is particularly so in relation to the incidence of postoperative complications and death.

Most recently von Meyenfeldt et $a l^{23}$ randomised patients with gastric or colorectal cancer to receive pre and postoperative enteral nutrition, total parenteral nutrition or control therapy. There was no significant difference in outcome or in any of the end points of the trial.

\section{POSTOPERATIVE EN $V$ TPN OR $V$ STANDARD} CONTROL NUTRITION

Heylen et $a l^{24}$ randomised 20 patients having total gastrectomy for cancer to a calorie regimen of $40 \mathrm{kcal} / \mathrm{kg} /$ day + amino acids through central vein or jejunostomy for eight days: there was no significant difference in postoperative outcome between the two groups except for the arm muscle circumference, which increased significantly more in the total parenteral nutrition than the enteral nutrition group.

Different results are obtained when enteral nutrition is compared with standard intravenous nutrition.

In a different study in which Sagar and associates $^{25}$ randomised 30 patients having major gastrointestinal surgery for presumed malignancy to receive either an elemental diet beginning on postoperative day one through a nasojejunal tube or standard intravenous fluids and a light diet, which was started on the sixth postoperative day. Control patients lost more weight, had a more negative nitrogen balance, and had a longer hospital stay than the group fed an elemental diet. Wound infection rates, however, were similar.

Daly et $a l^{26}$ prospectively studied the effects of immediate postoperative jejunostomy feeding in patients having a cystectomy and ileal conduit construction for bladder cancer. Twenty patients were randomised to receive an enteral diet by needle catheter jejunostomy or the standard postoperative $5 \%$ dextrose solution. Improved nitrogen balance was noted in the patients receiving enteral nutrition. The length of hospital stay, however, was similar between the groups; the incidence of infectious complications was not reported.

In a controlled, non-randomised study performed in our Institute ${ }^{7}$ in patients with squamous cell carcinoma of the oesophagus receiving chemotherapy and radiation therapy, we showed that an enteral nutrition regimen of $37 \mathrm{kcal} / \mathrm{kg} /$ day and $2 \cdot 1 \mathrm{~g}$ protein $/ \mathrm{kg} /$ day for one month could maintain the nutritional state of patients in the treatment group, which in turn deteriorated in the control group. No other benefits in terms of either compliance or response to the oncological treatment, or survival was described (Table V).

Enteral nutrition and oncological therapy There is a paucity of prospective, controlled evaluations of aggressive oral/enteral nutritional support as adjunctive therapy for oncology patients. Douglass et al 27 compared a supplemental oral elemental diet with between meal feedings in addition to standard diet in 30 patients receiving radiotherapy with or without adjuvant chemotherapy for a variety of locally advanced, non-resectable gastrointestinal malignancies. In this small study there was a trend toward improved skin test responses in those receiving the elemental diet. No differences in weight, total lymphocytes count, or survival were noted.

Daly et al ${ }^{9}$ investigated intensive nasogastric tube feeding (22 patients) $v$ optimal oral nutrition (18 patients) in patients with advanced head and neck cancer who were receiving eight weeks of radiation treatment. There was less weight loss in the tube fed group, and median albumin values returned towards normal in the tube fed group by the end of the treatment. There were no differences in response or survival rates; tube fed patients had significantly longer radiation toxicity, mean (SEM) $(3.3(1.9)$ weeks $v 1.8(0 \cdot 8))$.

\section{Enteral nutrition and tumour growth}

Scientific data on the effect of enteral nutrition on the tumoral growth in humans are scanty, anecdotal, 2829 and the results of two studies on patients with head-neck cancer is conflicting (Table VI).

We speculated that, if it is true that there is a relation between nutrient availability and tumour growth, then we should see the highest cancer cell proliferation rate in well nourished patients; consequently we tested this hypothesis statistically by evaluating the correlation between some nutritional variables (albumin, cholinesterase, number of lymphocytes, and body weight loss) with the labelling index in 136 adult patients with non-Hodgkin's lymphoma. The results obtained (Table VII) in this large population of patients do not support the view that a good nutritional state could result in a faster tumour growth as the opposite statistical association was found.

Our present view therefore is that any

TABLE VI Enteral nutrition and tumoral growth in patients with head-neck cancer

\begin{tabular}{lcl}
\hline & Baron $^{30}$ & Edstrom $^{31}$ \\
\hline $\begin{array}{l}\text { No of patients } \\
\text { Regimen }\end{array}$ & 6 & 13 \\
kcal/kg/day & $43 \cdot 1$ & $\operatorname{RME~} 1 \cdot 2-1 \cdot 5$ \\
AA/kg/day & $1 \cdot 4$ & 1 \\
Follow up (days) & $8 \cdot 0$ & $6-8$ \\
Tumoral growth & No change in \% & Increase in \% \\
& HC or AC & AC, DNA index, \\
& & ODC \\
\hline
\end{tabular}

HC=hyperdiploid cells; $\mathbf{A C}=$ aneuploidic cells;

ODC = ornithin decarboxylase activity; RME =resting metabolic expenditure. 
TABLE VII Association between labelling index and nutritional variables in 136 patients with non-Hodgkin's lymphoma

\begin{tabular}{|c|c|c|c|}
\hline & Labelling inde & $c(\%)$ & \\
\hline & $\operatorname{Low}(n=72)$ & $\operatorname{High}(n=64)$ & $x^{2}$ \\
\hline $\begin{array}{l}\text { Albumin }(\mathrm{g} / \mathrm{dl}) \\
\quad 0-3.53 \\
3.54-3.99 \\
\geqslant 4\end{array}$ & $\begin{array}{l}21 \cdot 9 \\
37 \cdot 5 \\
40 \cdot 6\end{array}$ & $\begin{array}{l}44 \cdot 4 \\
30 \cdot 6 \\
25\end{array}$ & $\begin{array}{l}8 \cdot 1^{\star} \\
7 \cdot 4^{\star}\end{array}$ \\
\hline $\begin{array}{c}\text { Cholinesterase }(\mathrm{mU} / \mathrm{ml}) \\
0-2139 \\
2140-2739 \\
\geqslant 2740\end{array}$ & $\begin{array}{l}23 \cdot 4 \\
25 \\
51 \cdot 6\end{array}$ & $\begin{array}{l}10 \cdot 8^{\star} \\
43 \cdot 1 \\
33 \cdot 3 \\
23 \cdot 6\end{array}$ & $11 \cdot 9^{\star}$ \\
\hline $\begin{array}{c}\text { Lymphocytes }\left(\mathrm{No} / \mathrm{mm}^{3}\right) \\
0-1479 \\
1480-2129 \\
\geqslant 2130\end{array}$ & $\begin{array}{l}25 \\
35 \cdot 9 \\
39 \cdot 1\end{array}$ & $\begin{array}{l}41 \cdot 7 \\
26 \cdot 4 \\
31 \cdot 9\end{array}$ & $4 \cdot 3$ \\
\hline $\begin{array}{l}\text { Body weight loss } \\
\text { Yes } \\
\text { No }\end{array}$ & $\begin{array}{l}23 \cdot 4 \\
76 \cdot 6\end{array}$ & $\begin{array}{l}41 \cdot 7 \\
58 \cdot 3\end{array}$ & $5^{\star}$ \\
\hline
\end{tabular}

${ }^{\star} \mathrm{p}=0.05$.

conclusion about the relation between nutrition and tumour growth is premature, and that if indicated no patient should be denied nutritional support for fear that this will result in stimulation of tumour growth.

\section{Home enteral feeding in cancer patients} Malignancy accounts for more than $40 \%$ of 1676 patients registered at the Oley Foundation and at different Commercial Home Nutrition Services. ${ }^{33}$ Gastrointestinal cancer particularly those with upper gastric intestinal tract disease accounts for about two thirds of the overall population of cancer patients. The average survival of these patients receiving home enteral nutrition is about four months longer than in the normal Italian experience of patients not receiving enteral nutrition support. ${ }^{34}$

We conclude that enteral nutrition is usually feasible in malnourished anorexic cancer patients even when they are receiving radiotherapy or chemotherapy. The nutritional efficacy of enteral nutrition is, however, limited.

Evidence from controlled clinical trials suggest that the main benefits are the maintenance of, or prevention of, further deterioration in nutritional state rather than restoration of normal nutritional state. At present there is no evidence that the effectiveness of radiotherapy or chemotherapy is enhanced by concomitant enteral nutrition. Nevertheless, it is indicated in patients receiving such treatment to preserve nutritional state. In our view, it would be unethical to randomise such patients in clinical trials to receive no nutritional support. As yet there is no proof that nutritional support enhances the kinetics of tumour kinetics. Clearly further work is required to characterise the cause of cancer cachexia. If it proves possible to counteract these then more benefits of concomitant nutritional support will probably, and hopefully, be identified.

1 Pareira MD, Conrad EJ, Hicks W, et al. Therapeutic nutrition with tube feeding. $¥ A M A$ 1954; 156: $810-6$

2 Pareira MD, Conrad EJ, Hicks W, et al. Clinical response and changes in nitrogen balance, body weight, plasma proteins and haemoglobin following the tube feeding in proteins and haemoglobin following the

3 Terepka AR, Waterhouse C. Metabolic observations during forced feeding of patients with cancer. Am $\mathcal{F}$ Med 1956; 20: 225-38.
4 Lim STK, Choa RG, Lam KH, et al. Total parenteral nutrition vs gastrostomy in the preoperative preparation of patients with carcinoma of the oesophagus. $\mathrm{Br} \mathcal{F}$ Surg 1981; 68: 69-72.

5 Burt ME, Gorschboth CM, Brennan MF. A controlled, prospective, randomized trial comparing the metabolic effects of enteral and parenteral nutrition in the cancer patient. Cancer 1982; 49: 1092-105.

6 Burt E, Stein TP, Brennan MF. A controlled randomized trial evaluating the effects of enteral and parenteral nutrition on protein metabolism in cancer bearing man. $\mathcal{F}$ Surg Res 1983; 34: 303-14.

7 Cozzaglio L, Bozzetti F, Bidoli P, Bonfanti G, Riva L, Strisciuglio A. Nutrizione enterale durante chemioradioterapia nel carcinoma esofageo. RINPE 1992; 10: $37-42$.

8 Balzola F, Palmo A, Protta F, et al. La terapia nutrizionale in pazienti portatori di neoplasia del capo collo in trattamento radiante. Parte prima: Dati antropometrici. RINPE 1984; 3: 30-54.

9 Daly JM, Herne B, Dunaj J, et al. Nutritional rehabilitation in patients with advanced head and neck cancer receiving radiating therapy. Am $\mathcal{F}$ Surg $1984 ; 148: 514-20$

10 Braga M, Cristallo M, Spiegel P, et al. Valutazione dello stato nutrizionale e alimentazione enterale nel paziente portatore di neoplasia del tubo digerente. RINPE 1983; 2: 30-40.

11 Bennegard K, Eden E, Ekman L, et al. Metabolic response of whole body and peripheral tissues to enteral nutrition in weight losing cancer and non cancer patients. Gastroenterology 1983; 85: 92-9.

12 Cristallo M, Braga M, Villa E, et al. Nutrizione enterale palliativa nel trattamento della malnutrizione del paziente neoplastico. RINPE 1984; 3: 19-30.

13 Ravera E, Radaelli G, Migliavacca S, et al. Effetti della nutrizione enterale sullo stato nutrizionale del pazienti con cachessia neoplastica. RINPE 1986; 4: 43-50.

14 James H, Fabricius $P$, Chettle D, et al. Whole body nitrogen and potassium measured by neutron activation analysis and whole body counting in malnourished cancer patients. RINPE 185; 3: 93-104.

15 Lundholm $\mathrm{K}$, Bennegard $\mathrm{K}$, Eden $\mathrm{E}$, et al. Efflux of 3-methylhistidine from the leg in cancer patients who experience weight loss. Cancer Res 1983; 42: 4807-11.

16 Bennegard $\mathrm{K}$, Lindmark L, Eden $\mathrm{E}$, et al. Flux of amino acids across the leg in weight-losing cancer patients. Cancer Res 1984; 44: 386-93.

17 Haffeejee AA, Angorn IB. Nutritional status and nonspecific cellular and humoral immune-response in oesophageal carcinoma. Ann Surg 1979; 189: 475-9.

18 De Vries EGE, Mulder NH, Houwen B, et al. Enteral nutrition by nasogastric tube in adult patients treated with intensive chemotherapy for acute leukemia. Am $\mathfrak{f}$ Clin Nutr 1982; 35: 1490-6.

19 Palmo A, Balzola F, Protta F, et al. La terapia nutrizionale in pazienti portatori di neoplasia del capo collo in trattamento radiante. Parte seconda: Dati ematici. RINPE 1984; 3: 55-70.

20 Nixon D, Lawson DH, Kutner M, Ansley J, et al. Hyperalimentation of the cancer patient with protein calorie undernutrition. Cancer Res 1981; 40: 2038-45.

21 Dresler CM, Jeevanandam M, Brennan MF. Metabolic efficacy of enteral feeding in malnourished cancer and noncancer patients. Metabolism 1987; 36: 82-8.

22 Sako K, Lore JM, Kaufman S, Razack MS, Bakamijan V, Reese P. Parenteral hyperalimentation in surgical patients with head and neck cancer: a randomized study. $¥$ Surg Oncol 1981; 16: 391-402.

23 von Meyenfeldt MF, Meijerink WJHJ, Rouflart MM, BuilMaassen MTHJ, Soeters PB. Perioperative nutritional support: a randomised clinical trial. Clinical Nutrition 1992; 11: $180-6$

24 Heylen AM, Lybeer MB, Penninckx FM, Kerremans RP, Frost PG. Parenteral vs needle jejunostomy nutrition after total gastrectomy. Clin Nutr 1987; 6: 131-6.

25 Sagar S, Harland P, Shields R. Early postoperative feeding with elemental diet. $B M \mathcal{F} 1979 ; 1: 293-5$.

26 Daly JM, Bonau R, Stofberg P, et al. Immediate postopera tive jejunostomy feeding: clinical and metabolic results in a prospective trial. Am $\mathcal{f}$ Surg 1987; 153: 198-206.

27 Douglass HO Jr, Milliron S, Nava H, et al. Elemental diet as an adjuvant for patients with locally advanced gastrointestinal cancer receiving radiation therapy: a prospectively randomized study. FPEN 1978; 2: 682-6.

28 Bell JW, Jesseph JE, Leighton RS. Spontaneous regression of bronchogenic carcinoma with 5-year survival. $\mathcal{F}$ Thora Cardiovasc Surg 1964; 48: 984-90.

29 English WJ, Suskind M, Damorongsak D. Can the growth of a neuroblastoma be influenced by a child's nutrition state? Clin Pediatr 1975; 14: 868-9.

30 Baron PL, Lawrence W Jr, Chan WMY. Effects of parenteral nutrition on cell cycle kinetics of head and neck cancer. Arch Surg 1986; 121: 1282-6.

31 Edstrom S, Westing T, Delle V, et al. Cell cycle distribution and ornithine decarboxylase activity in head and neck cancer in response to enteral nutrition. Eur 7 Cancer Clin Cancer in response to en

32 Bozzetti F, Boracchi P, Cozzaglio L, Costa A. The nutritional status of the cancer patients does not affect the tional status of the cancer patients does not affect
tumour growth. Clinical Nutrition 1991; suppl 2: 12 .

33 Howard L, Heaphey LL, Timchak N. A review of current nutritional status of home parenteral and enteral nutrition from the provider and consumer perspective. $尹 P E N 1986$; 10: 416-24.

34 Corti T, Salis C, Cazzaniga R, Fossa D. Nutrizione enterale a domicilio. Tre anni di esperienza. RINPE 1987; 5: 189-92. 